\title{
New Actors in Rural Development - The LEADER Approach and Projectification in Rural Croatia
}

\author{
Aleksandar Lukić \\ University of Zagreb, Faculty of Science, Department of Geography, Croatia \\ e-mail: alukic@geog.pmf.hr
}

\section{Orlanda Obad}

Institute of Ethnology and Folklore Research, Zagreb, Croatia e-mail: orlanda@ief.hr

\begin{abstract}
LEADER has often been praised as a successful approach to rural development, although its implementation is not without scholarly critiques. The aim of this paper is to contribute to the understanding of how LEADER, now in its initial phase in Croatia, operates within the shifting local power relations in rural areas. We focus on questions concerning the social background of the new LEADER project class, financing, the influence of local politics and the trust and involvement of the local population. Since factors contributing to success and failure of EU programmes have often been attributed to their localization into a specific territorial context, among other things, we use a regional and typological approach in selecting 10 LAGs for conducting in-depth semi-structured interviews. The results indicate that, in relation to the local territorial context, the differentiation between the internal and external project classes might be useful as an analytical tool. Furthermore, we have confirmed that there might be pitfalls in using financial criteria as the only instrument of assessment for evaluation which disregards whether the projects implemented are inclusive and responsive to the needs of the whole of local populace - which runs contrary to the basic tenets of LEADER. Finally, the role of local politics has been specifically identified in two diametrical territorial contexts (rural periphery, and more dynamic developed areas).
\end{abstract}

Key words: LEADER, projectification, project class, rural development, actors, Croatia. 


\section{Introduction}

The LEADER programme provides context for researching the emergence of new actors and power relations in rural Croatia, especially through projectification. LEADER ("Liaison Entre Actions de Développement de l'Économie Rurale", meaning "Links between the rural economy and development actions") is a local rural development method launched in 1991 by the European Commission as a Community Initiative. LEADER approach focuses on engaging the energy and resources of people and bodies as development actors rather than beneficiaries, by forming area based Local Action Group (LAG). LAGs are territorial partnerships between public, civil and private sector, the most visible manifestation of LEADER. LEADER began during a period marked by important changes in the EU's political discourse concerning rural areas - underway since the beginning of the 1980s. Up to that point, the heavily funded Common Agricultural Policy, envisaged in the 1960s, had certainly achieved its aims of feeding the Community and providing financial security to (some) farmers. However, it was becoming more and more evident that the sectorial top-down created and managed approach to territorial development had resulted in numerous unforeseen and undesired consequences, such as increasing demographic and economic polarization, monotonous cultural landscapes, a reduction in biological biodiversity, and pollution of groundwater due to the increased use of pesticides and fertilizers, etc. (EC, 1999). Simultaneously, in spite of the agricultural orientation of development of the time, it was already apparent that rural areas were becoming more and more diverse and multifunctional, and that their societal functions had expanded far beyond food production. The Future of Rural Society (EC, 1988) is often heralded as the first political expression of the new rural development paradigm, which promoted an endogenous, integrated and territorial approach (Ray, 2000). A few years later, LEADER became the first manifestation of this political shift, although similar approaches, based on integrated principles, were already present on local levels throughout Europe (Bruckmeier, 2000; Schucksmith, 2010; Dax et al., 2013).

In Croatia, LEADER was officially implemented in 2013 during the implementation of IPARD ${ }^{1}$ (Rural Development Programme of the Republic of Croatia for the Period 2014-2020 [RDP Croatia], 2015:574). However, the LEADER approach came into view in Croatia in 2004 with the publication "LEADER, from Initiative to Method - A guide to teaching the LEADER approach" (Laginja, 2004) - a translation of original publication published with EU support within LEADER II. In 2006 the Croatian Rural Development Network (Hrvatske mreža za ruralni razvoj - HMRR) organized the first national conference on rural development titled "Rural development in Croatia - opportunities and challenges". The work of international organizations such as PREPARE and ECOVAST also had an influence on developing new ideas and

1 IPARD is a pre-accession Programme of the EU which was in force in Croatia for the period of 2007 - 2013. It is an integral part of the IPA (Instrument for Pre-accession Assistance), with the main objectives of assisting candidate countries and potential candidate countries with the harmonisation and implementation of the EU acquis, as well as preparation for utilisation of the future EU funds. (http://www.mps.hr/ipard, 22.10.2015.) 
strengthening partnerships in rural development. The first registered Croatian LAG was the Gorski Kotar LAG, founded in 2008 during the project "Sustainable future of Croatian rural areas" run by HMRR and numerous NGOs in Croatia together with international partners. In 2010 the HMRR and NGO "Odraz" published the book "Zajedno za održivi razvoj ruralnih područja-Priručnik za provedbu LEADER pristupa u Hrvatskoj". In 2012 the LEADER Network of Croatia was founded as a new network of LAGs and other institutions involved in rural development. Today, both the Croatian Rural Development Network (HMRR) and the LEADER Network Croatia are members of the European LEADER Association for Rural Development (ELARD). It is evident that the LEADER approach, including the formation of first LAG, was developed through civil sector efforts. In 2008, the Ministry of Agriculture founded the department for the LEADER programme and agro-environmental schemes as a part of its EU-SAPARD/IPARD oriented course. ${ }^{2}$ LEADER became a part of the Croatian Rural Development Strategy of 2007-2013, the predecessor of the contemporary RDP, and soon LAGs started to appear, beginning with the pilot project run by the Ministry. The number of LAGs grew steadily and in 2013 and 2014, and 42 of them have since been accredited and financed based on the quality of their Local development strategies through an open call in IPARD measure 202. In one of the rare studies of Croatian LAGs, Tolić and Markotić Krstinić (2015) reveal that in the year following the contracting and approval, Croatian LAGs organized 632 training workshops and 516 information sessions. The number of participants in trainings organized by LAGs came close to 2400, and there were more than 50,000 participants overall in the organized informational and promotional activities.

Today, LEADER (CLLD) is a part of measure 19 of the Croatian RDP for 2014-2020, with a budget of around 67 mil. kn. ${ }^{3}$ There are 61 local action groups in Croatia today, encompassing almost $90 \%$ of territory of Croatia. ${ }^{4}$ More than half of the Croatian population live in local administrative units included in LAGs. ${ }^{5}$

One of the prevalent ways of executing EU programmes, LEADER included, is through projects. The project class and "projectification" as a process with broad societal consequences (cf. Packendorff and Lindgren, 2014) have already been recognized as important factors in the implementation of EU rural policies, and especially in new member states (cf. Kovách and Kučerová, 2006; 2009). Our analysis will focus on LAG representatives, as they are directly locally involved in the processes of

2 Uredba o unutarnjem ustrojstvu Ministarstva poljoprivrede, ribarstva i ruralnog razvoja, NN $35 / 2008$.

3 Precisely, 67,540,725.00 kn (2.83\% of the total RDP budget). In October 2015, under measure 19.1., the first wave of funding, totalling $18,142,142.11 \mathrm{kn}$, was allocated to 50 selected LAGs for the preparation of their local development strategies and operating costs.

4 The number of LAGs in Croatia is constantly changing and both the Croatian Rural Development Network (HMRR) and the Leader Network Croatia provide different data. The data used in this paper rely on desk and field research conducted for a graduate thesis supervised by one of the authors of the paper.

5 Precisely, 2,391,805 inh. Or 55.81\% of total population. 
projectification in rural areas, while remaining aware of territorial differences among the different geographical contexts in which they operate. Bearing in mind that the implementation of LEADER in Croatia is officially only two years old and that the financial framework has enabled LAGs to introduce mostly preparatory activities for future programme implementation, our aim is to contribute to the understanding of how LEADER operates in its initial phase in Croatia with regard to the shifting local power relations in rural areas brought about by the accession process. In this study, we will focus on questions concerning the social background of the new LEADER project class, financing, influence of the local politics, and the trust and involvement of the local population.

Apart from the introduction and conclusion, the paper consists of two chapters setting the theoretical framework for our research (The successes and failures of LEADER, and LEADER and the rise of the project class), research methodology, and a chapter devoted to analysis and discussion.

\subsection{The successes and failures of LEADER}

A quarter of a century since the beginning of LEADER, the official rhetoric of the EU praises it as a successful approach to rural development, as an example of an innovative method proven to be so useful and effective that its main principles and modus operandi have been, as of 2014, transferred to urban areas, through the "community-led local development" program (CLLD) (Regulation EU 1303/2013). This is the latest step in LEADER's development, after it was integrated (mainstreamed) into the national Rural Development Programme (RDP) of 2007-2013. Together with the budget increase, mainstreaming has certainly helped in "shifting the programme from the margins towards the centre of rural policy influence" (Dax et al, 2013). Furthermore, it is a rare case in which rural development has provided the blueprint for its urban counterpart, which, we would argue, already makes LEADER a success story, at least symbolically.

In the context of rural development in Western European countries, which is still heavily dominated by the disintegrated sectorial approach (Shucksmith, 2010), both academics and practitioners often find the well-known LEADER approach and its guiding principles, i. e. development which is area-based, bottom-up, public-private, integrated, innovative, co-operative and involving networking, overly idealistic and impractical. Nevertheless, the number of Local action groups (LAGs) rose steadily during the last 25 years and today there are almost 2500 of them. Simultaneously, their total public budget grew more than 7 times. ${ }^{6}$

$\mathbf{6}$ The number of LAGS increased from 217 in 1991 to 2402 in 2013 and are currently covering $77 \%$ of total EU territory. Their total public budget simultaneously grew from 1.2 billion euros to 9.2 billion euros enabling the support of almost 100,000 local projects EU-wide (ENRD, 2014). 
It would seem obvious to conclude that the value of LEADER goes beyond its symbolic importance and that it does have some real effects, at least in terms of numbers. For that reason only, it was no surprise that the EU members which acceded in the 2000s expected (and hoped) that the LEADER programme would dynamize their rural development (Bíró and Györke, 2009; Eszter, 2011; Marquardt et al., 2010). However, the programme implementation in Central-Eastern Europe also provoked some critical tones (e.g. Marquardt et al., 2010) in line with reviews of LEADER effects in the old EU (Shucksmith, 2010; Dax et al., 2013). Starting from the analysis of the application of LEADER in Austria and Ireland, Dax et al. (2013) note the increased "banalization" of LEADER projects, and the shift away from innovative or experimental projects which lead to less certain or predictable outcomes. The authors stress that "the economic crisis has contributed to the perception that matching budgetary targets takes preference over local community development needs" (p. 9), and they also assert that the enforced regulatory framework impedes the feasibility of innovative projects (ibid.). Dax et al. (2013) also assert that increased regulation reduces the ability of LEADER to quickly respond to the ever-changing needs of local areas, which has reduced the autonomy of local LAGs (ibid: 10). The bottom-up approach, as one of the basic tenets of the program, has thus been threatened with replacement by "a much more top-down reality" (ibid.). In a study of the application of LEADER in Romania, Marquardt et al. (2010) detect similar threats to both the bottom-up approach and endogenous development. The authors point out the difficulties that LAGs face in following "the identified regional needs and opportunities" (p. 222), and endogenous development under the LEADER program was somewhat impeded by the scope of measures within which LAGs were supposed to operate. Some research also points out that "there is no evidence of the effectiveness of the LEADER programme and the added value of its approach" (ECA, 2010; Schuh et al., 2006 in Marquardt et al., 2010:198). If a region is funded under LEADER, it does not necessarily entail that the principles of LEADER are followed in practice (Böcher, 2008; ECA, 2010 in Marquardt et al., 2010:198).

Researchers conducting research on the implementation of LEADER programme have already posed the question of whether it is an elitist or an inclusive program, and critical examinations of LEADER implementation have, so far, offered varying answers to this question (cf. Thuesen, 2009:32). In a study of LEADER programme practices in the UK, which focuses on the nexus between endogenous development, social capital and social inclusion, Shucksmith (2001) poses the somewhat provocative question of whether "'collective' capacity-building through territorially-based endogenous development" is, indeed, "compatible with building the capacities of excluded individuals and redistributing power towards the least powerful" (p. 209). The much-praised territorial approach is enacted through a "symbolic construction of culture-territories," which, in reality, consist of individuals with different, and sometimes even conflicting interests, so that the attempted "flattening" of the differing socioeconomic positions to the formula of "empowering the local" may actually blur and neglect the existing social inequalities and exclusions (cf. ibid: 210). The author asserts that "[t]here is a tendency for endogenous development initiatives to favour those who are already powerful and articulate, and who already enjoy a greater capacity to act and to engage with the initiative" (p. 215). 
The LEADER programme has also been occasionally criticized because of its gradual commercialization or failed implementation (or loss of) some of its professed features, which make it an allegedly innovative tool in rural development. Consider, for example, Bruckmeier's (2001) compelling analysis of the introduction of the LEADER program in Germany, in which the particular form of regional development in former West Germany was impacted by the alternative ecological concepts originally developed within the new social movements (NSM). It is precisely within the discourse of the NSMs that the discourse on rural areas, once predominantly preoccupied with food production, was "ecologized" and broadened to include notions such as sustainability, landscape preservation, and renewable energy (Bruckmeier, 2001:220). Bruckmeier (2001) goes on to examine the changes that the original program underwent after it was linked with the LEADER-initiative in the 1990s and concludes that "with LEADER, rural development projects became more politically controlled, standardized and administered ... in effect, LEADER has played a catalytic role in the functional integration of the NSMs into the established societal system" (p. 221).

Finally and of symbolic importance, LEADER is still heavily under-budgeted in comparison to other measures in the RDP. If it is so successful, why is this not visible (where it really matters) in terms of funding?

The question we can pose regards factors influencing the success and failure of LEADER, and if we go beyond the numerical and statistical indicators literature suggests that at least part of the answer could be found in the specificities of each country, more precisely, in their political, administrative, socio-economic, historical and cultural context (Marquardt et al., 2010:198 based on Bruckmeier 2000; Jouen, 1999). The argument of the importance of territorial (national, regional, local) context for the success or failure of EU programmes such as LEADER, can also be found in Harboe Knudsen's (2012) response to the predominant analytical approaches to the processes of Europeanization in Central and Eastern Europe. Harboe Knudsen (2012) coined the slightly altered term "EUropeanization", which emphasizes the importance of location and context within which the application of particular EUrelated changes is taking place. Instead of approaching member states as simply implementing EU rules and regulations, the author talks about "locally processed EUs" (p. 5). Since "EU programs often do not fit into the local environment and people's ways of doing things ... people are bound to change them and adjust them to their daily life" (ibid.).

\subsection{LEADER and the rise of the project class}

In contrast to the more traditional sectoral approach to rural development there is the trend of projectification in rural areas, which is important for understanding programs such as LEADER (cf. Kovách and Kučerová, 2006; 2009). Kovách and Kučerová (2009) examine various determinants of the current rise of the project class, among which they detect the concurrent processes of decentralization and neobureaucratization which are taking place in rural areas across Europe (p. 206, cf. 
also Kovách and Kučerová, 2006:10-11). Also, the "shift from a direct to an indirect model of intervention from policy centres" has created a demand for "properly constructed projects", and "actors with the intellectual capacity to design and manage programmes and networks" (ibid. 2009:207). The implementation of "projectified" EU programmes has necessitated the participation of skilled mediators, who are proficient in the particular project lingo and are acquainted with the concepts and frameworks which are currently in demand within rural development policies on various levels.

Members of the project class have attained an important role in the mediating and translating of concepts, ideas and frameworks from "higher" to "lower" strata, and they "are required to have both sufficient imagination to identify 'local wellbeing' and sufficient skills in application systems" (Kovách and Kučerová, 2006:9). These projectification processes are taking place within the context of thoroughly culturalized approaches to rurality across Europe (cf. Kovách and Kučerová, 2009:208-209), which are intertwined with the predominant logic of commercialization and its accompanying marketing strategies (cf. ibidem, 2006:16; also, 2009:211).

The project class is relatively new to rural areas, especially so in the Croatian context, and current research suggests that its role in the administration and distribution of programmes such as LEADER should be further scrutinized. Kovách and Kučerová (2009) summarize some typical characteristics of the members of the project class in the following manner:

They are often individuals with considerable power over the projectified economic, social and political institutions and the social environment. They have high, often tertiary-level education and strong intellectual capital. Their income, prestige and influence is mainly based on their mediatory, expert, social and economic position and power in development and other projects. They have the social capital for networking but the project class does not occupy a specific occupational position. Experts, managers, counsellors, planners, practitioners, researcher and teaching staff, other intellectuals, representatives of civil society institutions and bureaucratic staff on varying levels of governments from the EU to local administration whose economic, societal and symbolic position and livelihood is linked to short- or long-term projects can be seen as members of the new cognitive class (ibid.:210).

\section{Research methods: semi-structured interviews based on territorial contextualization of the LEADER programme in Croatia}

In order to statistically compare the rurality of Croatia and of the EU on a more general territorial level, the best possible tool is probably the recently updated Urban-rural typology used by EUROSTAT. It reveals that Croatia is a noticeably more rural country than the EU average, with more than double the average EU share of population in predominantly rural regions $(22.3 \%$ in the EU and $56.7 \%$ in Croatia). 
Table 1

Urban-rural typology EUROSTAT (NUTS-3)

\begin{tabular}{|c|c|c|c|c|c|c|}
\hline & \multicolumn{3}{|c|}{ Population (\%) } & \multicolumn{3}{c|}{ Area (\%) } \\
\hline & $\begin{array}{c}\text { Predominantly } \\
\text { urban regions }\end{array}$ & $\begin{array}{c}\text { Intermediate } \\
\text { regions }\end{array}$ & $\begin{array}{c}\text { Predominantly } \\
\text { rural regions }\end{array}$ & $\begin{array}{c}\text { Predominantly } \\
\text { urban regions }\end{array}$ & $\begin{array}{c}\text { Intermediate } \\
\text { regions }\end{array}$ & $\begin{array}{c}\text { Predominantly } \\
\text { rural regions }\end{array}$ \\
\hline EU-27 & 42.4 & 35.3 & 22.3 & 9.9 & 38.7 & 51.4 \\
\hline CROATIA & 18.0 & 25.3 & 56.7 & 1.1 & 30.8 & 62.9 \\
\hline
\end{tabular}

Source: Eurostat: Urban-rural typology update

According to the definition often used in Croatian academic discourse, rural areas account for $45.8 \%$ of the total population. ${ }^{7}$ Unfortunately, they are in great part synonymous with problem areas possessing negative demographic, economic and social features. ${ }^{8}$ However, the respective depopulation and deagrarization, urbanization, industrialization and littoralization processes (to mention only the most influential), differ significantly in their spatial effects, and contribute to the heterogeneity of rural areas. Typology of rural and urbanized settlements, based on PCA and cluster analysis, has shown important differences between various types of non-urban settlements in Croatia: dynamic, structurally stronger rural and urbanized settlements (1); accessible, commuting dependent rural and urbanized settlements (2); market oriented agricultural rural and urbanized settlements (3); economically diversified, mainly tourist rural and urbanized settlements (4); rural and urbanized settlements of extensive agriculture and weaker demographic structure (5) and rural periphery (6) ${ }^{9}$ (Lukić, 2012).

The typological approach is one of the main methodological instruments for applying the idea of territorial context to developmental programmes. Territorial context, understood as specificities of rural communities emerging from their political, administrative, socio-economic, historical, and cultural environment has been recognized not only as an important factor contributing to the success or failure of LEADER (Marquardt et al., 2010:198 based on Bruckmeier 2000; Jouen 1999), but also as a sine qua non of contemporary rural development. Rural areas take many forms and the challenges that different areas face require intelligent, regionally targeted responses (Brunori and Rossi, 2007; Halfacree, 2006; Cloke, 2006; OECD, 2006; Rienks, 2008; SCENAR 2020; Woods, 2005).

7 Settlements have been declared urban, rural, and/or mixed by combining demographic (number of inhabitants) and various socio-economic variables (share of agricultural population, share of persons employed outside of the primary sector, share of agricultural households etc.). This approach was also the foundation of official statistical model of differentiation of urban, rural and semi-urban settlements in the Republic of Croatia (Ostroški, 2011).

8 Numerous research confirms this claim: Akrap, 2002; Lay, 2002; Nejašmić and Štambuk, 2003; Štambuk, 2002; Štambuk and Mišetić, 2002; Živić, 2002; Župančić, 2005.

9 Number corresponds to the types in Tab. 2. 
In our study we follow a regional and afore-mentioned typological approach in selecting LAGs in all the three main geographical regions in Croatia (Littoral, Mountainous and Lowland Croatia) and also encompassing all different types of rural and urbanized settlements according to typology. The number of selected LAGs per geographical macroregion corresponds with the total number of LAGs in each one.

Table 2

Selection of LAGs included in research based on geographical and typological specificities of rural areas in Croatia

\begin{tabular}{|l|l|l|}
\hline Geographical macroregion & $\begin{array}{l}\text { Predominant types of rural and urbanized } \\
\text { settlements for interviewed LAGs }\end{array}$ & Number of researched LAGs \\
\hline LAGs in Littoral Croatia & $4,3,1,5$ & 3 \\
\hline LAGs in Mountainous Croatia & 5,6, & 1 \\
\hline LAGs in Lowland Croatia & $2,1,5,6$ & 6 \\
\hline
\end{tabular}

Source: Lukić, 2012

We conducted ten semi-structured interviews with representatives of Croatian LAGs. Some of the interviews were conducted in person, during field work conducted in July, 2015, while the others, due to various constraints, were conducted over the telephone in July, August and September of the same year. An average interview lasted an hour and a half. We also held several follow-up interviews for the purposes of clarification and deepening insights. We are aware of the fact that ten interviews, although that number accounts for every sixt LAG in Croatia, may pose limitations in interpreting the results. However, our aim was to uncover current practices and has not been focused on judging their representativeness in terms of number or similar. Nevertheless, we have selected LAGs by the regional and typological approach in order to make the analysis more valid. Time and budget constraints were the main reasons for selected number of LAGs in the research.

\section{Analysis and discussion}

\subsection{The rise of the LEADER project class in rural Croatia}

In this research, our focus is on the management of projects and other daily LAG activities, including the day-to-day relations with LAG members and citizens of the LAG area, which is the reason why our sample of interviewees consists predominantly of LAG managers, who are called "leaders" in Croatia ${ }^{10}$. Their function involves the daily executive engagement in conducting of LAG activities, the organization and execution of its projects, the implementation of strategic and miscellaneous

10 Out of the ten interviews, seven were conducted with the LAG „leaders“, and three others with LAG representatives highly involved in the functioning of the LAG. 
decisions reached by other LAG bodies, as well as the goals defined in their key document - the local development strategy (LDS). ${ }^{11}$

Most of our interviewees could, indeed, be considered representatives of what Kovách and Kučerová (2006; 2009) term the "project class", a relatively new actor in rural development whose important position of translator and mediator between the higher, abstract policy spheres and funding opportunities, on the one hand, and the local (rural) context, on the other. As we shall attempt to demonstrate in the following analysis, our interviewees belong to a peculiar section of the rural "project class", one whose function is placed at the crossroads between civil society (LAGs in Croatia are formally registered as non-governmental organizations), the public service (how LAGs often define their own role in the society), and the economically-driven logic of success of project funding possibilities on the "open market". In the conducted interviews most of the LAG representatives clearly distinguish their own role from the role of the "real" profit-driven project class embodied by private consultants - such as those contracted to aid in writing LAG local development strategies. A common critique of a stereotypical consultants' approach is that they often resorted to "copy-pasting" while writing up strategies, or that they were insufficiently sensitive to the local context. However, a smaller number of interviewees also single out positive examples in which consultants significantly contributed to the articulation of an LDS.

In response to Kovách and Kučerova's (2009) assertion that "little is known about the social composition of the new groups appearing in development projects", we can offer a sketch of a typical interviewee included in this research. All of our interviewees are highly educated people with university degrees in various academic fields, many in various subfields of economics. The majority of them were born and raised in villages or small towns located in the territory now encompassed by the LAG. Most of them have "rural" experience, meaning the experience of living in a village and also participating in agricultural activities. Many of those who were born and raised in small towns also consider themselves closely related to the "rural" through relations with close family relatives "in the countryside" or through everyday exposure to the codified symbols of rural life.

The typical education and career trajectory of our interviewee consists of obtaining a university education in a larger city and returning to their place of origin directly afterwards. Or, acquiring certain work experience in a city or a smaller town first, and then returning to the area of origin when an adequate job opportunity arose. For some of the interviewees, especially the youngest ones, their position in the local LAG was their "ticket back home", or their first more permanent work experience.

11 A LAG is officially represented by its president, who is usually employed in another position, such as head of local town or municipality, while other important LAG bodies may include, for example, the general assembly, executive board and supervisory board. Since LAGs in Croatia are legally registered as NGOs, their management structure is defined in their statute. 
Almost without exception, our interviewees speak English, and most often another foreign language, as well. Before they were employed with their LAG, the vast majority of them had obtained substantial experience in project management in various sectors. It should be noted that having a university degree, as well as proficiency in project management, have already been singled out as advantages in the assessment LAGs underwent in order to obtain financing under IPARD,${ }^{12}$ since LAG "leaders" who had such qualifications were awarded more "points".

\subsection{Local political context and financing of LAGs}

The structure and membership of LAGs was often discussed at the beginning of interviews, and two major points were usually underscored. The first being methods of financing, a topic closely related to the issue of membership fees; the second being political influence on LAG activities, which is most palpable in their relationship with the representatives of local administrative units. Towns and municipalities which are LAG members, are, in most examined cases, an important source of membership fees for LAGs, and therefore important factors in contributing to the stable functioning of LAG activities. ${ }^{13}$

Almost every LAG involved in this research has a different approach to financing and membership fees - which vary greatly among LAGs. Some interviewees report that the measures which ensured pre-financing through interest-free loans from the Croatian National Foundation for Civil Society Development, as well as credit loans from commercial banks, combined with a relatively steady influx of membership fees provide them with a satisfying degree of financial stability. Others, however, report considerable insecurity and financial instability related to irregular or insufficient payment of membership fees, or, in some examples, the failure of certain towns or municipalities to pay their fees at all. In such a financial setup, LAGs seem to be forced to incessantly juggle different financial sources, and are also pressured to continuously negotiate their funding with various LAG members (local towns and municipalities are often the largest contributors) which can considerably drain LAG resources. Similar findings, e.g. "poor cash-flow of LAGs and the impossibility to ensure funds for pre-financing", were also noted by the Croatian Rural Development Programme as possible risks in the implementation of LEADER for the period of 2014-2020 (RDP Croatia, 2015:584).

Some LAG representatives report that the increased financial dependence on local administrative units also increases the LAG's potential vulnerability to political pres-

12 Cf. Pravilnik o provedbi Mjere 202 - 'Priprema i provedba lokalnih strategija ruralnog razvoja' unutar IPARD programa, Narodne novine 24 od 2013.

13

Only officially accredited LAGs were financed through IPARD Measure 202, which does not cover all of their expenses, such as, various contributions to salaries. During the implementation of Measure 202, LAGs received their funding from IPARD post festum (after they had performed their activities), which meant that, in order to function and fulfill plans they needed to have money available in the meantime. 
sures. Aware that direct dependence on funding from local towns and municipalities could expose them to political influence, one LAG leader organized intense activities directed toward gathering "smaller" membership fees from many individual members, such as local entrepreneurs, and this LAG eventually succeeded in securing almost 50 percent of its funding through such fees. It required extensive usage of LAG resources but it also, as stated in the interview, increased this particular LAG's familiarity with its membership "base".

In some cases "leaders" of LAGs tend to regard their own position as uncertain as opposed to "safe" or "secure". ${ }^{14}$ This is because the salaries of "leaders" are, to a certain extent, dependent upon the amount of money that the LAG gathers through membership fees. Aware of the importance of funding for the LAG's future, some interviewees admit to having spent more of their energy in the initial period of leadership securing steady sources of financing, rather than completing of all of the goals determined by their initial local development strategy.

Some interview accounts indicate that ensuring the basic financing of the LAG proved to be a challenging task, demanding the deployment of various financial strategies and negotiating skills. One interviewee informs us that sometimes the heads of local administrative units failed to understand why they would be expected to provide the money from their budgets, if there was nothing offered immediately in return. Furthermore, several interviewees worry that during the period of 2014-2020, the pressure on LAGs could increase considerably as LAGs will have access to substantially larger funding through measure 19 of the Croatian RDP. As one of the interviewees puts it, it is foreseeable that towns and municipalities might pressure the LAGs to develop projects which would primarily benefit them and people they support, without necessarily taking into account the larger perspective involving different sectors - as is envisaged by LEADER. This is reminiscent of earlier research findings in Hungary and the Czech Republic, in which during the process of the rise of the project class "certain power holders, including the State, continue to dominate the resulting networks which remain, in reality, hierarchical" (Kovách and Kučerova 2006:12).

The independent evaluators in the Croatian RDP already noted the "dominant influence of local government on LAG work/overdependence of LAGS on the units of local self-government" (RDP, 2015:584). In one of the LAGs we reached out to in this study, political change on the local level caused, as one interviewee recounts, intense pressure on the LAG to replace its president with a person who would be closer to the new party in power. As this LAG was, from its very inception, impacted by the local politics, it was perceived more as an extension of the local government than as an independent body involved in rural development.

14 As Kovách and Kučerova (2009) assert, an important trait of the "project class" is that its representatives are "permanently in danger of losing its source of income and must make a great deal of effort to ensure a minimal income at a standard level if higher profit has not been reached" (p. 215). Some LAG "leaders" had permanent contracts, while others' were hired on a temporary or renewable basis. Some of the LAG representatives included in this research have experienced delays in receiving their salaries, for instance. 
In contrast to that, we also encountered LAGs which were rather unconcerned with local politics. They say that the local politicians understand the positive impact LAGs can make in their environment, and (of equal importance) that in the upcoming period there would be enough money available for the development of each and every town and municipality, if the energy is only focused on developing high-quality project ideas. Such positive examples, however, are encountered in the areas in which the overall level of local development is considerably above-average, where the role of the private and civil sectors are much more pronounced, and local politics remains but one of a range of factors impacting the performance of LAGs. For the least developed areas we include in our research (especially those still struggling with the post-war legacy, combined with high unemployment and poverty rates and the nation-wide trend of depopulation), the interviews seem to revolve much more around local politics. These interviewees admit that, even though they are highly motivated and willing to contribute to the local community, they are losing their resolve and considering leaving their current job - and as a result the area where they were born and raised. However, the greatest majority of cases examined here fall between these two distinct developmental poles. In them, political influence on LAGs seems to vary, and is more difficult to relate directly to the general developmental context, statistical indicators such as the development index, or to fit neatly within the typology.

Certain LAG actions, with their lightweight, postmodern capacity to circumvent the existing structures of governance and assume actions which could be interpreted as closer to "participative democracy", might be perceived as "a threat to the legitimate institutions of representative democracy" (Ray, 2001:168). We have encountered examples of LAG actions which involved ad hoc actions intended to help a particular segment of the local population - especially in response to unexpected circumstances and emergencies. Such actions were sometimes praised, and at other times criticized by the local governments as stepping outside the LAG's domain of authority.

The wide range of ways in which the LAGs practice their supposedly common agenda of rural development once again confirms the "often observed capacity of local practitioners to interpret any policy according to their ideological beliefs or local circumstances" which, in the end, has a direct "material impact on policy implementation" (Ray, 1999b in Ray, 2001:170). This assertion resonates with Harboe Knudsen's (2012) concept of EUropeanization, which helps us differentiate between the concept and desired implementation method of a given EU policy, and its eventual realization within a particular social context.

\subsection{Trust and involvement of the local population}

Another axis of conversation, and a problem which seems to appear in almost all of the LAGs we contacted, is the issue of gaining the trust of the local population, and finding ways to motivate "common citizens" to participate in LAG activities and apply for their own projects. 
Our interviewees almost all state that the average "peasant" (an owner of a small family farm), is not nearly knowledgeable or skilled enough to participate in the projectified rural development funding discussion on equal footing. ${ }^{15}$ The bottom-up approach, as one of the interviewees puts it, does not function as imagined when applied to this segment of the population. Though an important feature of LEADER's endogenous development hypothesis, as suggested by Ray (2001), is "contextualized by focusing on the needs, capacities and perspectives of local people" (p. 166), and it "assumes an ethical dimension by emphasizing the principle and process of local participation in the design and implementation of action through the adoption of cultural, environmental and 'community' values ..." (p. 166). As critical assessments of the LEADER program have already detected, it is debatable what LEADER actually delivers in terms of the professed bottom-up approach (cf. Dax et al., 2013; Marquardt et al., 2010).

The interviews give abundant examples of difficulties that LAG "leaders" (and other representatives we talked to) encountered in relations with potential "users" of LAG services, the major problem being insufficient understanding of the requirements and procedures for the creation and implementation of the projects involved. At times, a class-related hierarchical discourse would develop, drawing a clear line between the "uneducated" peasants and the representatives of the "knowledgeable" project class. More often, though, one could sense a genuine concern regarding this gap, with some interviewees admitting to intentionally breaching the lines of professional conduct and getting involved in highly personalized relationships with the "locals". Regardless of the stance, the interviewees agree that individuals with whom LAGs come into contact have different starting points in terms of their economic, social, and cultural capital, and that the efforts to include representatives of disadvantaged or marginalized groups consume considerably more resources, such as time (cf. Shucksmith, 2000:215).

Interestingly, it seems that LAGs in Croatia have approached this problem with differing tactics. Some of them seem to retain a primarily consulting and coordinating function, insisting that their focus is on developing strategies, strengthening local capacities, establishing networks between various sectors, and offering education and information related to various funding opportunities. A representative of one such LAG explains that it makes sense to work with those who are more ready to adapt to the principles of project application, as those people will serve as motivators to their surroundings in the further rounds of project funding. Furthermore, motivating segments of the population that are uninterested or suspicious toward joining might drain LAG resources with little chance of producing the desired effect. Finally, an overprotective approach could also instil passivity into the potential users making them unwilling to master the skills necessary for them to become more self-reliant in future project applications.

15 Research on differences between the educational structure of rural and urban populations in Croatia revealed that $4,2 \%$ of the rural population and $1,7 \%$ of the urban poulation have no education at all. The urban-rural difference is the most pronounced in the share of population with a high university or similar degree: $16,8 \%$ in urban and only $4,8 \%$ in rural areas (Lukić, 2012). 
Representatives of those LAGs which have decided to assume a more engaged and activist-minded approach, or to focus more actively on including the less skilful and expedient individuals and groups in the processes of projectification, have reported increased strain and long(er) working hours. Still, in some areas the decision to work more closely with the segments of the population, which would otherwise most likely remain excluded from LAG activities, has been shown as one way to ensure the building of trust within the local community. A representative from one such LAG says that if she came to her local community and offered yet another talk about the possibilities for funding and potential for change, it would not be persuasive, since it is a story those people have heard many times over which has disappointed them for its lack of tangible results. This interviewee stresses direct involvement with the local population as the most important contribution of the introduction of LAGs in rural areas.

\section{Conclusion}

In this article, we attempt to examine several factors which impacted the implementation of the LEADER programme in Croatia. Croatia is particularly convenient for such a study, as the newest EU member state, which only recently began to implement certain programmes that have already been in effect in some of the older member states for decades, and also as a state in which the processes of projectification in rural areas are still in their initial phases.

We follow Kovách and Kučerová's (2006; 2009) suggestion, which says that it may be important to pay closer attention to the ways in which members of the so-called project class are involved in rural development, by taking into account their "social background", their "education and values" (2009:204), and the ways they network, exert power and employ their social capital. In this study, we approach the LAG "leaders" as somewhat atypical members of the project class. Their tertiary education, their proficiency in project management, knowledge of English, and familiarity with the policy framework within which programmes such as LEADER are implemented, distinguish them considerably from the rural social milieu in which they operate and also provide them with a privileged position of skilful mediator between the institutional framework of rural policies and local stakeholders. Still, it is important to re-state that in the interviews conducted, LAG "leaders" often perceive themselves as different from the representatives of the "real" project class, such as consultants. Many of them also share a common understanding, according to which their own function in the rural areas would be close to the general function of the public service - benefiting the "common citizen".

A conspicuous trait, at least among the interviewees included in this research is that they, as a rule, originate from the area recently encompassed by the LAG. Their close, personal relation to the territory, and their rootedness in the local social context, may be interpreted as running somewhat contrary to "the ability to move around", "from problem to problem, subject to subject" which, according to Sennett (2006:115), "resembles the work of consultants" (ibid.). In this research, consultants 
are predominantly perceived as representatives of the project class which is external in relation to local rural development. Usually hired as professional help in specific tasks, they are expected to continuously shift tasks and look for new professional opportunities among LAGs.

Our interviewees seem to be part of another kind of project class, which is internal in relation to the local rural development, and which often seems to be more personally and existentially involved with the surroundings in which it operates. As projectified forms of funding distribution are being introduced more often, e.g. through LEADER mainstreaming in CAP, as permanent forms of development of rural areas, it might be that the kind of project class accompanying such development has adjusted accordingly in that it appears rooted rather than mobile. In conclusion, there seem to be many different criteria to distinguish between different types of project classes, in relation to the local territorial context. The differentiation between the internal and external project class has emerges as analytically useful in the opinion of the authors.

In the context of Croatia, with its Local Action Groups still in their initial stages of development, it is too early for a comprehensive analysis of the impact of the LEADER programme on rural development. Still, some differences between LAGs have emerged already, and it will be of particular interest to continue observing how the LAGs will handle the increased pressure of their potential clients (from the actors which have proven to be among the most influential in the initial period, such as local towns and municipalities, all the way down to the "ordinary peasants", as proverbial holders of the least social and cultural capital) during the period of 2014-2020. It remains to be seen whether LAGs in Croatia will empower the disempowered or decide to "favor those who are already powerful and articulate" (Shucksmith, 2001:215).

Regardless of the paths taken by individual LAGs, we believe that evaluations of LAG performance, and projects aimed at segments of the population which require more LAG resources in order to be successfully incorporated into rural development as ideally envisaged by LEADER, should be awarded special attention in the future. In the dominant political and public discourse in Croatia, the successful implementation of EU-funded projects is primarily assessed through the percentage of allocated finances used. Our research confirms that there are pitfalls to such an approach. Evaluation which disregards whether the projects implemented are inclusive and responsive to the needs of the whole of local populace (such as a bottom-up, participatory approach or innovativeness), runs contrary to the basic tenets of LEADER. Simply including the less advantaged segments of the society in the drafting and preparing of the LDS is not a guarantee in itself that the money actually spent will address their needs in the end.

Finally, the political influence on LAG's work is evident from our research. The importance of local politics is particularly visible in two diametrical territorial contexts. On the one hand, there is the typical example of a rural periphery, where negative demographic and socio-economic conditions prevail. Due to those structural disad- 
vantages, developmental opportunities are limited mostly to the local government, ending with its dominant influence on all spheres of life, LAG activities included. On the other hand, LAGs in rural areas marked with stronger population and economic structures are less exclusively dependent upon local government/politics due to more diversified developmental options in the private and civil sectors. However, more detailed and representative research is needed in order to confirm and explore recognized connections between local politics and LAGs.

\section{Acknowledgements:}

This work has been supported in part by the Croatian Science Foundation under the project number 4513. Any opinions, findings, and conclusions or recommendations expressed in this material are those of the author(s) and do not necessarily reflect the views of Croatian Science Foundation.

\section{References}

1. Akrap, A. (2002). Regionalne i naseljeske značajke vitalnih procesa u hrvatskom seoskom stanovništvu, u: Štambuk Maja, Rogić Ivan i Mišetić Anka (Ur.). Prostor iza: kako modernizacija mijenja hrvatsko selo. Zagreb: Institut društvenih znanosti Ivo Pilar.

2. Bitáné Bíró, B. and Koponicsné Györke, D. (2009). Leader activity in the South Transdanubian Region. Journal of Central European Agriculture, 10 (2): 123132.

3. Bruckmeier, K. (2001). LEADER in Germany and the discourse of autonomous regional development. Sociologia ruralis, 40 (2): 219-227.

4. Brunori, G. and Rossi, A. (2006). Differentiating countryside: Social representations and governance in rural areas with high social density: The case of Chianti, Italy. Journal of Rural Studies, 23 (2): 183-205.

5. Cloke, P. J. (2006). Conceptualizing rurality, in: Cloke, Paul, Marsden, Terry and Mooney, Patrick (Eds.). Handbook of Rural Studies. London: Sage Publications Ltd.

6. Dax, T.; Strahl, W.; Kirwan, J.; Maye, D. (2013). The Leader programme 20072013: enabling or disabling social innovation and neo-endogenous development? Insights from Austria and Ireland. European Urban and Regional Studies, published online 26 July 2013. (http://dx.doi.org/10.1177/0969776413490425).

7. EC, (1988). The future of rural society. Luxembourg: European Commission (EU).

8. EC, (1999). European Spatial Development Perspective, Towards Balanced and Sustainable Development of the Territory of the European Union. Luxembourg: Office for Official Publications of the European Communities.

9. Eszter, B. (2011). The LEADER program in Hungary and in Europe. Journal of Central European Agriculture, 12 (3): 486-497.

10. Halfacree, K. (2006). Rural space: constructing a three-fold architecture, in: Cloke, Paul, Marsden, Terry and Mooney, Patrick (Eds.). Handbook of Rural Studies. London: Sage Publications Ltd. 
11. Harboe Knudsen, I. (2012). Effects and outcomes of EUropeanization in rural Lithuania. London, New York, Delhi: Anthem Press.

12. Kovách, I. and Kučerová, E. (2006). The project class in Central Europe: the Czech and Hungarian cases. Sociologia ruralis, 46 (1): 3-21.

13. Kovách, I. and Kučerová, E. (2009). The social context of project proliferation the rise of a project class. Journal of Environmental Policy E Planning, 11 (3): 203-221.

14. Laginja, I. (Ur.) (2004). LEADER od inicijative do metode, Vodič za poduku o LEADER-ovu pristupu. Zagreb: ZOE - Centar za održivi razvoj ruralnih krajeva.

15. Lay, V. (2002). Prilozi osmišljavanju usmjeravanja razvitka ruralnih prostora Hrvatske na osnovama ekološke i gospodarske održivosti, u: Štambuk Maja, Rogić Ivan i Mišetić Anka (Ur.). Prostor iza: kako modernizacija mijenja hrvatsko selo. Zagreb: Institut društvenih znanosti Ivo Pilar.

16. Lukić, A. (2012). Mozaik izvan grada - tipologija ruralnih i urbaniziranih naselja Hrvatske. Samobor: Meridijani.

17. Marquardt, D.; Wegener, S. and Möllers, J. (2010). Does the EU LEADER instrument support endogenous development and new modes of governance in Romania?: experiences from elaborating an MCDA based regional development concept. International Journal of Rural Management, 6 (2): 193-241.

18. Nejašmić, I. and Štambuk, M. (2003). Demografsko stanje i procesi u neurbanim naseljima Republike Hrvatske. Društvena istraživanja, 3-4 (65-66): 469-493.

19. OECD, (2006). OECD Rural Policy Reviews: The New Rural Paradigm, Policies and Governance. Paris: OECD Publishing.

20. Ostroški, Lj. (2011). Model diferencijacije urbanih, ruralnih i prijelaznih naselja u Republici Hrvatskoj, Metodološke upute 67. Zagreb: Državni zavod za statistku.

21. Packendorff, J. and Lindgren, M. (2014). Projectification and its Consequences: Narrow and Broad Conceptualisations. South African Journal of Economic \& Management Sciences, 17 (1): 7-21.

22. Rienks, W. A. (Ed.) (2008). The future of rural Europe: An anthology based on the results of the Eururalis 2.0 scenario study. Wageningen: Wageningen University Research and Netherlands Environmental Assessment Agency.

23. Scenar 2020-II, (2009). Executive summary for the 'Update of Analysis of Prospects in the Scenar 2020 Study'. 26 ${ }^{\text {th }}$ October 2014. (http://ec.europa.eu/agriculture/analysis/external/scenar2020ii/summary en.pdf).

24. Shucksmith, M. (2010). Disintegrated Rural Development? Neo-endogenous Rural Development, Planning and Place-Shaping in Diffused Power Contexts. Sociologia Ruralis 50 (1): 1-14.

25. Sennett, R. (2006). The Culture of the New Capitalism. New Haven \& London: Yale University Press.

26. Štambuk, M. (2002). Selo i modernizacija: kratka povijest nesporazuma, u: M. Štambuk, I. Rogić, i A. Mišetić, (Ur.). Prostor iza: kako modernizacija mijenja hrvatsko selo. Zagreb: Institut društvenih znanosti Ivo Pilar, 9-28.

27. Štambuk, M. i Mišetić, A. (2002). Neki elementi socijalne i tehnničke infrastrukture hrvatskog sela, u: Štambuk Maja, Rogić Ivan i Mišetić Anka (Ur.). Prostor iza: kako modernizacija mijenja brvatsko selo. Zagreb: Institut društvenih znanosti Ivo Pilar. 
28. Tolić, S. and Markotić Krstinić, B. (2015). Implementation of LEADER measures of rural development in Croatia. Journal of Hygienic Engineering and Design, 10: 41-48.

29. Živić, D. (2002). Odabrane značajke demografske strukture seoskih naselja u Hrvatskoj 1953.-1991. godine, u: M. Štambuk, I. Rogić, i A. Mišetić, (Ur.). Prostor iza: kako modernizacija mijenja brvatsko selo. Zagreb: Institut društvenih znanosti Ivo Pilar, 9-28.

30. Župančić, M. (2005). Infrastrukturna opremljenost hrvatskih seoskih naselja. Sociologija sela, 169 (3): 617-657.

31. Woods, M. (2005). Rural Geography: Processes, Responses and Experiences in Rural Restructuring. London: Sage Publications Ltd.

\section{Sources}

1. ENRD, (2014). LEADER infographic. $15^{\text {th }}$ September 2015. (http://enrd.ec.europa. eu/en/home-page).

2. Eurostat, Urban-rural typology update. 22 ${ }^{\text {nd }}$ September 2015. (http://ec.europa. eu/eurostat/statistics-explained/index.php/Urban-rural typology update).

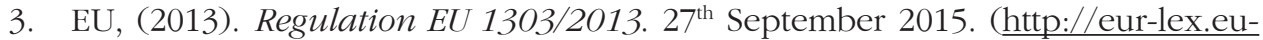
ropa.eu/LexUriServ/LexUriServ.do?uri=OJ:L:2013:347:0320:0469:EN:PDF).

4. Ministarstvo poljoprivrede, (2015). Program ruralnog razvoja Republike Hrvatske za razdoblje 2014.-2020., Popis mjera s osnounim informacijama. $2^{\text {th }}$ September 2015. (http://ruralnirazvoj.hr/files/documents/MPS program-ruralnograzvoja-RH 200x275 v6-LQ.pdf).

5. Pravilnik o provedbi Mjere 202 - 'Priprema i provedba lokalnih strategija ruralnog razvoja' unutar IPARD programa. Narodne novine 24 od 2013.

6. Rural Development Programme of the Republic of Croatia for the Period 20142020 (RDP Croatia), (2015). 12 October 2015. (http://www.mps.hr/ipard/UserDocsImages/Postpristupno\%20razdoblje\%20\%20EAFRD/PRR\%202014-2020\%20 finalna\%20inačica\%20EN/Adopted RDP2014-2020 ENG 26May2015.pdf).

7. Uredba o unutarnjem ustrojstvu Ministarstva poljoprivrede, ribarstva i ruralnog razvoja, Narodne novine 35 od 2008. 
Prethodno priopćenje

\section{Aleksandar Lukić}

Sveučilište u Zagrebu, Prirodoslovno-matematički fakultet, Geografski odsjek, Hrvatska

e-mail:alukic@geog.pmf.hr

Orlanda obad

Institut za etnologiju i folkloristiku, Zagreb, Hrvatska

e-mail: orlanda@ief.hr

\section{Novi akteri ruralnog razvoja - LEADER program i proces projektifikacije u ruralnim područjima Hrvatske}

\section{Sažetak}

LEADER se često ističe kao uspješan primjer programa ruralnog razvoja, iako se brojna znanstvena istraživanja istovremeno i kritički osvrću na njegovu implementaciju. Cilj ovog članka pridonijeti je razumijevanju djelovanja lokalnih akcijskih grupa (LAG-ova) u Hrvatskoj u inicijalnoj fazi službene implementacije LEADER-a i u uvjetima stvaranja novih odnosa moći u ruralnim područjima. Naglasak je na socijalnim obilježjima nove projektne klase povezane $s$ LEADER-om, pitanjima financiranja, utjecaja lokalne politike, povjerenja i uključenosti lokalne zajednice. Metodološki okvir rada predstavlja geografski i tipološki pristup ruralnim područjima Hrvatske, kako bi LAG-ovi odabrani u uzorak odražavali demogeografsku, gospodarsku i socijalnu raznovrsnost ruralne Hrvatske. S predstavnicima izabranih LAG-ova provedeni su dubinski polustrukturirani intervjui. Rezultati upućuju da je u kontekstu povezanosti s lokalnim područjem djelovanja, u analitičkom smislu, podjela projektne klase na vanjsku i unutarnju mogući novi način njezina promatranja. Nadalje, iako se financijski indikatori uspješnosti projekta (iskorištenost sredstava) često koriste kao jedini ili vodeći kriteriji vrednovanja, istraživanje je pokazalo da se samo njima ne može utvrditi vjerodostojnost primjene načela LEADER-a, odnosno odgovor na najvažnije potrebe lokalnih zajednica. Utjecaj lokalne politike posebno je bio izražen u dvama suprotnim prostornim kontekstima: bio je vrlo izražen u slučaju primjera ruralne periferije i gotovo ga nema u slučaju demografski dinamičnijih i ekonomski razvijenijih ruralnih područja.

Ključne riječi: LEADER, projektifikacija, projektna klasa, ruralni razvoj, akteri, Hrvatska. 